PNNL-12111

\title{
Distribution of Components in Ion Exchange Materials Taken from the K East Basin and Leaching of Ion Exchange Materials by Nitric/Hydrofluoric Acid and Nitric/Oxalic Acid
}

CH Delegard

DE Rinehart

FV Hoopes

November 23, 1998

Prepared for

Numatec Hanford Corporation

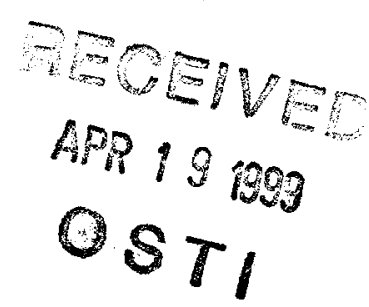

Work Supported by

the U.S: Department of Energy

under Contract DE-AC06-76RLO 1830

Pacific Northwest National Laboratory

Richland, Washington 99352 


\title{
DISCLAIMER
}

This report was prepared as an account of work sponsored by an agency of the United States Government. Neither the United States Government nor any agency thereof, nor Battelle Memorial Institute, nor any of their employees, makes any warranty, express or implied, or assumes any legal liability or responsibility for the accuracy, completeness, or usefulness of any information, apparatus, product, or process disclosed, or represents that its use would not infringe privately owned rights. Reference herein to any specific commercial product, process, or service by trade name, trademark, manufacturer, or otherwise does not necessarily constitute or imply its endorsement, recommendation, or favoring by the United States Government or any agency thereof, or Battelle Memorial Institute. The views and opinions of authors expressed herein do not necessarily state or reflect those of the United States Government or any agency thereof.

\author{
PACIFIC NORTHWEST NATIONAL LABORATORY \\ operated by \\ BATTELLE \\ for the \\ UNITED STATES DEPARTMENT OF ENERGY \\ under Contract DE-AC06-76RLO 1830
}

Printed in the United States of America

Available to DOE and DOE contractors from the

Office of Scientific and Technical Information, P.O. Box 62, Oak Ridge, TN 37831;

prices available from (615) 576-8401.

Available to the public from the National Technical Information Service, U.S. Department of Commerce, 5285 Port Royal Rd., Springfield, VA 22161

This document was printed on recycled paper. 


\section{DISCLAIMER}

Portions of this document may be illegible in electronic image products. Images are produced from the best available original document. 


\section{Summary and Conclusions}

Laboratory tests were performed to examine the efficacy of mixed nitric/hydrofluoric acid followed by mixed nitric/oxalic acid leach treatments to decontaminate ion exchange materials that have been found in a number of samples retrieved from $\mathrm{K}$ East (KE) Basin sludge. The ion exchange materials contain organic ion exchange resins and zeolite inorganic ion exchange material. Based on process records, the ion exchange resins found in the $\mathrm{K}$ Basins is a mixed-bed, strong acid/strong base material marketed as Purolite NRW-037. The zeolite material is Zeolon-900, a granular material composed of the mineral mordenite. Radionuclides sorbed or associated with the ion exchange material can restrict its disposal to the Environmental Restoration Disposal Facility (ERDF). The need for testing to support development of a treatment process for $\mathrm{K}$ Basin sludge has been described in Section 4.2 of "Testing Strategy to Support the Development of K Basins Sludge Treatment Process" (Flament 1998).

Elutriation and washing steps are designed to remove the organic resins from the $\mathrm{K}$ Basin sludge. To help understand the effects of the anticipated separation steps, tests were performed with well-rinsed ion exchange (IX) material from KE Basin floor sludge (sample H-08 BEAD G) and with well-rinsed IX having small quantities of added KE canister composite sludge (sample KECOMP). Tests also were performed to determine the relative quantities of organic and inorganic IX materials present in the $\mathrm{H}-08 \mathrm{~K}$ Basin sludge material. Based on chemical analyses of the separated fractions, the rinsed and dry IX material H-08 BEAD G was found to contain 36 weight percent inorganic material (primarily zeolite). The as-received (unrinsed) and dried H- 08 material was estimated to contain 45 weight percent inorganic material.

Prior engineering and laboratory studies investigated two leach treatment methods for the IX materials. In the first method, $6 \underline{\mathrm{M} \mathrm{HNO}} 3 / 0.4 \underline{\mathrm{M}} \mathrm{Ce}(\mathrm{IV})$ was contacted with the rinsed IX material and with the sludge-amended IX material. In the second method, sequential leach contacts with $4 \mathrm{M} \mathrm{HNO}_{3}$ followed by $0.1 \underline{\mathrm{M}} \mathrm{HNO}_{3} / 0.2 \mathrm{M} \mathrm{H} \mathrm{H}_{2} \mathrm{O}_{4}$ were performed with the $\mathrm{IX}$ material and sludge-amended $\mathrm{IX}$ material.

The two-step nitric/oxalic acid treatment generally gave better overall solids decontamination than the $\mathrm{Ce}$ (IV) treatment. In both cases, the presence of added sludge severely increased the concentrations of uranium, plutonium, and americium in the treated residues. However, the TRU concentrations in the residues were consistently lower for the nitric/oxalic treatment than for the $\mathrm{Ce}(\mathrm{IV})$ treatment. The better performance of nitric/oxalic was almost solely because of its better removal of plutonium for the tests both with and without added sludge. Comparison of the test data for the leachants also showed that better

${ }^{137} \mathrm{Cs}$ and ${ }^{241} \mathrm{Am}$ decontamination was obtained by leaching at higher acid concentrations. Other comparative studies to investigate the leaching of residues produced by nitric acid treatment of $\mathrm{K}$ Basins sludge showed mixed $6 \underline{\mathrm{M} \mathrm{HNO}} 3 / 0.3 \underline{\mathrm{M}} \mathrm{HF}$ gave the best decontamination.

Because of the improved ${ }^{137} \mathrm{Cs}$ and ${ }^{241} \mathrm{Am}$ removal from the IX materials at higher acid concentrations and the improved decontamination of dissolver residues afforded by $6 \underline{\mathrm{M} \mathrm{HNO}} 3 \mathrm{~N} / 3 \mathrm{M} \mathrm{HF}$, additional testing was performed to use this solution as the initial step to treat $\mathrm{IX}$ materials. The second step remained the successful $0.1 \mathrm{M} \mathrm{HNO}_{3} / 0.2 \mathrm{M} \mathrm{H}_{2} \mathrm{C}_{2} \mathrm{O}_{4}$ demonstrated previously. The test results show the expected better decontamination for ${ }^{137} \mathrm{Cs}$. However, for the key TRU constituents, ${ }^{239,240} \mathrm{Pu}$ and ${ }^{241} \mathrm{Am}$, the enhancements provided by the higher acid concentration and HF in the first leach contact of the RESIN tests were marginal. Overall, about $1 / 4$ to $1 / 3$ less plutonium and americium were present in the solid residues remaining from the tests with $6 \mathrm{M} \mathrm{HNO}_{3} / 0.3 \mathrm{M} \mathrm{HF}$ than in the tests with $4 \mathrm{M} \mathrm{HNO}$. In the tests without added sludge, the ERDF criterion was met for plutonium and slightly exceeded for americium. With 
added sludge, the ERDF criteria for plutonium and americium are exceeded 8- and 35-fold, respectively. Clearly, the presence of added sludge has the most serious effect on meeting the ERDF criteria. 


\section{Contents}

Summary and Conclusions .......................................................................................................... iii

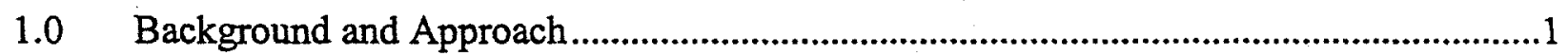

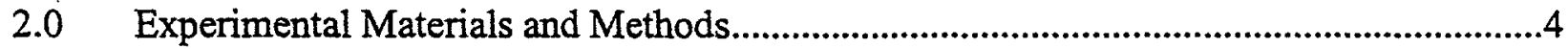

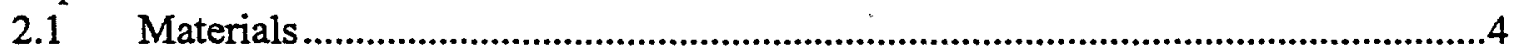

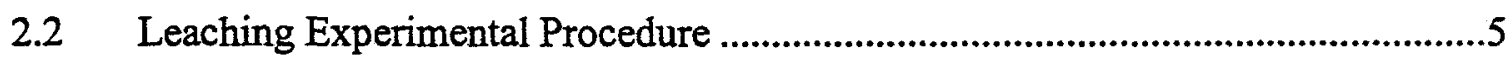

2.3 Analyses ............................................................................................................6

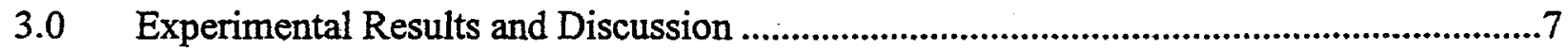

3.1 Qualitative Observations ...........................................................................................

3.2 Analyses and Composition of Starting Materials......................................................

3.3 Leachate Analyses.................................................................................................9

3.4 Leach Residue Analyses...................................................................................10

3.5 Material Balances .......................................................................................1

3.6 Decontamination Factors..........................................................................13

3.7 Distribution Coefficients .............................................................................14

3.8 Dissolution Coefficients ................................................................................15

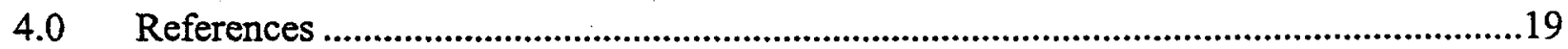




\section{Tables}

1 Leachants and Material Weights in Present and Prior Leach Testing..............................5

2 Radiochemical Concentrations and Quantities in the Starting Materials..........................8

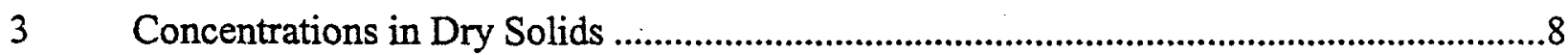

4 Radiochemical Concentrations in Test Leachates....................................................10

$5 \quad$ Radiochemical Concentrations in Test Residues .......................................................10

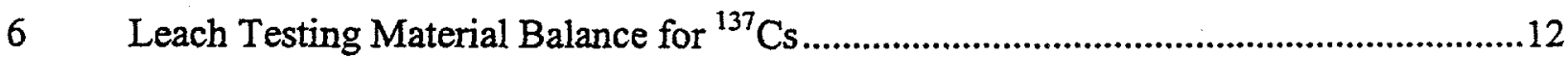

$7 \quad$ Leach Testing Material Balance for Uranium .........................................................12

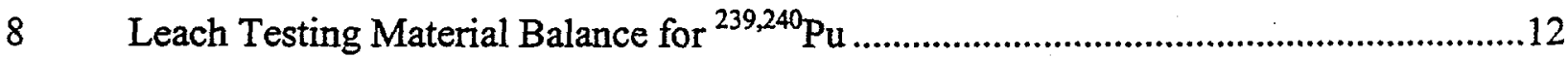

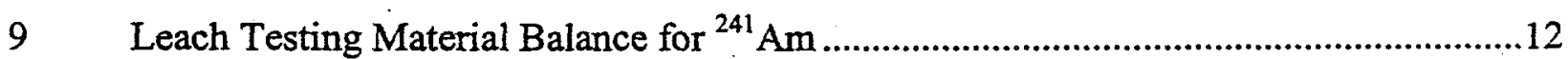

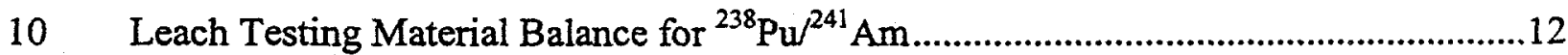

11 Leach Testing Material Balance for Total Alpha .....................................................13

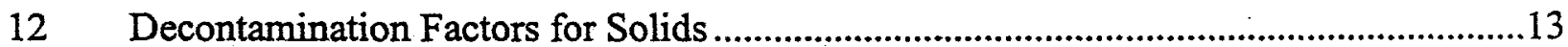

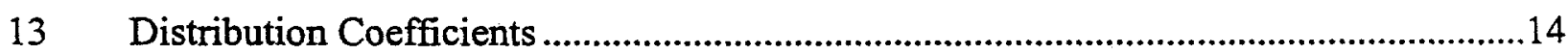

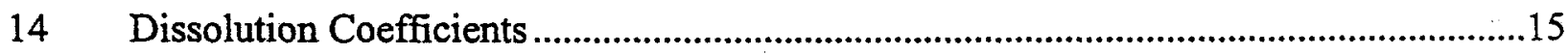


Figures

1 Dried and Fractionated Material from Sample H-08 ...................................................16

2 Dried and Fractionated Material from Sample H-08 BEAD G........................................17

3 Scanning Electron Photomicrograph of H-08 BEAD G IX Materials .............................18 


\subsection{Background and Approach}

Ion exchange (IX) materials are found in sludges from the $\mathrm{K}$ Basins. Characterization and process testing has shown that the IX materials contain both organic ion exchange resins (OIER) and inorganic zeolite ion exchangers. Based on process records, the OIER found in the $\mathrm{K}$ Basins is a mixed-bed, strong acid/strong base material marketed as Purolite NRW-037. The zeolite is Zeolon-900, a granular material composed of the mineral mordenite. Tests were performed to examine alternative methods to decontaminate the IX materials. Background information, the laboratory testing, and the experimental results are described and presented in this report.

Solid residues, including IX materials, to be delivered to the Environmental Restoration Disposal Facility (ERDF) from chemical treatment of $\mathrm{K}$ Basin sludge must meet Waste Acceptance Criteria (WAC) for radionuclide concentrations (Bechtel 1998). The radionuclides most likely limiting the ERDF acceptance of $\mathrm{K}$ Basin solid residues are ${ }^{137} \mathrm{Cs}\left(32 \mathrm{Ci} / \mathrm{m}^{3}, 32 \mu \mathrm{Ci} / \mathrm{mL}\right.$ or $32 \mu \mathrm{Ci} / \mathrm{mL}$ at $1 \mathrm{~g} / \mathrm{mL}$ solids density for IX materials) and the transuranics (TRU; $100 \mathrm{nCi} / \mathrm{g}$ ). The TRU isotopes have individual limits: ${ }^{241} \mathrm{Am}, 0.05 \mathrm{Ci} / \mathrm{m}^{3}(50 \mathrm{nCi} / \mathrm{mL}$ or $50 \mathrm{nCi} / \mathrm{g}) ;{ }^{238} \mathrm{Pu}, 1.5 \mathrm{Ci} / \mathrm{m}^{3}(1500 \mathrm{nCi} / \mathrm{mL}$ or nCi$/ \mathrm{g})$; and ${ }^{239} \mathrm{Pu}$ and ${ }^{240} \mathrm{Pu}, 0.029 \mathrm{Ci} / \mathrm{m}^{3}(29 \mathrm{nCi} / \mathrm{mL})$ each. Because ${ }^{239} \mathrm{Pu}$ represents about $3 / 4$ of the combined measured ${ }^{239,240} \mathrm{Pu}$ activity in Hanford products, and the ${ }^{238} \mathrm{Pu}$ limit is relatively high in comparison with its isotopic concentration, the ERDF Criterion for plutonium is established by ${ }^{239} \mathrm{Pu}$. The ${ }^{239} \mathrm{Pu}$ limit is equivalent to $44 \mathrm{nCi}^{239,240} \mathrm{Pu} / \mathrm{mL}$ or $44 \mathrm{nCi}^{239,240} \mathrm{Pu} / \mathrm{g}$. The effective uranium limit for disposal to ERDF, $0.0026 \mathrm{~g} \mathrm{U} / \mathrm{mL}^{1}$ or $0.0026 \mathrm{~g} \mathrm{U} / \mathrm{g}$ solid, also has the potential to restrict certain $\mathrm{K}$ Basins residues. The final waste form for residual solids (of which IX materials will be constituents) must meet these levels to allow disposal to ERDF. A sum of fractions criterion likely will be applied.

The TRU concentrations in water-rinsed and -dried IX material taken from the K East (KE) Basin (sample KES-H-08) range from $647-844 \mathrm{nCi} / \mathrm{g}$. Unrinsed IX material contains $144 \mu \mathrm{Ci}{ }^{137} \mathrm{Cs}$ and $0.003 \mathrm{~g} \mathrm{U}$ per gram of dried material (Schmidt et al. 1999). Sample KES-H-08 contains spherical OIER beads and irregularly shaped white granules approximately $1 \mathrm{~mm}$ long. The granules were identified by $\mathrm{X}$-ray diffractometry (XRD) as mordenite and arise from use of Norton Industries Zeolon-900 in the treatment of K Basin water to remove ${ }^{137} \mathrm{Cs}$ (Schmidt et al. 1998).

Tests on the elution/loading behavior of sample KES-H-08 (containing both OIER and Zeolon-900 ${ }^{\mathrm{TM}}$ ) on contact with $10 \underline{\mathrm{M} \mathrm{HNO}} 3$ followed by $10 \underline{\mathrm{M}}$ acid and water rinsing were conducted in prior scoping studies (Schmidt et al. 1999). The tests showed that about $80 \%$ of the U, $25 \%$ of the $\mathrm{Pu}$, and $70 \%$ or more of the Am were removed at ratios of about $1 \mathrm{~g}$ solids per $20 \mathrm{~mL}$ acid. Cesium distributions were unmeasured. Residual activities in the acid-treated OIER were $110-190 \mathrm{nCi}^{239,240} \mathrm{Pu} / \mathrm{g}, 20-120 \mathrm{nCi}$ ${ }^{241} \mathrm{Am} / \mathrm{g}$, and $1.5-34 \mu \mathrm{Ci}^{137} \mathrm{Cs} / \mathrm{g}$. Uranium concentrations were undetectable but likely were near $0.0003 \mathrm{~g} \mathrm{U} / \mathrm{g}$ based on $\mathrm{K}_{\mathrm{d}}$ tests at higher loadings. Thus, multiple wash contacts of IX materials with strong $\mathrm{HNO}_{3}$ may remove $\mathrm{Cs}, \mathrm{U}$, and Am to meet ERDF criteria. However, strong $\mathrm{HNO}_{3}$ washing

\footnotetext{
${ }^{1}$ The ERDF WAC limit for ${ }^{238} \mathrm{U}$ and its daughters is $0.012 \mathrm{Ci} / \mathrm{m}^{3}$. With 8 alpha and 6 beta decays in the ${ }^{238} \mathrm{U}$ decay chain and a specific activity of $3.36 \times 10^{-7} \mathrm{Ci}{ }^{238} \mathrm{U} / \mathrm{g}$, the specific activity of the ${ }^{238} \mathrm{U}$ chain is $4.7 \times 10^{-6} \mathrm{Ci} / \mathrm{g}$. The ERDF limit for ${ }^{238} \mathrm{U}$ thus is $0.00256 \mathrm{~g}{ }^{238} \mathrm{U} / \mathrm{mL}$. The ERDF limit for ${ }^{235} \mathrm{U}$ (daughters not included) is $0.0027 \mathrm{Ci} / \mathrm{m}^{3}$ and the specific activity of ${ }^{235} \mathrm{U}$ is $2.16 \times 10^{-6} \mathrm{Ci} / \mathrm{g}$. Thus the ERDF limit for ${ }^{235} \mathrm{U}$ is $0.0013 \mathrm{~g}{ }^{235} \mathrm{U} / \mathrm{mL}$. The relative limits of the two uranium isotopes, and the nominal $0.7 \%{ }^{235} \mathrm{U}$ enrichment of the $\mathrm{K}$ Basins sludge, mean that ${ }^{238} U$ concentration limits ERDF disposal. Therefore, the effective uranium limit for disposal to ERDF is $0.0026 \mathrm{~g} \mathrm{U} / \mathrm{mL}$.
} 
would be unsuccessful for Pu where high anion exchange sorption on OIER occurs at high $\mathrm{HNO}_{3}$ concentrations.

The radionuclide contamination associated with the IX materials may be physically adsorbed as radioactive particles or may be ion exchanged on the IX materials themselves. Rinsing of IX materials in the elutriation step will achieve some physical removal of the adsorbed radioactive particles. The remaining radioactivity associated with the particles must be removed to levels acceptable to ERDF by, for example, acid leaching. At the same time, radionuclides associated with the IX materials may be dissolved by total dissolution of the IX material itself, defunctionalization of the IX material (to destroy its ion exchange capacity), or elution. Both OIER and Zeolon-900 (mordenite) have demonstrated ruggedness to destruction or defunctionalization in hot concentrated nitric acid (Pool et al. 1998a and $1998 \mathrm{~b}$, respectively).

Because of this stability, ion exchange elution was chosen as the preferred method to decontaminate OIER. An engineering study identified chemical agents to leach or elute radioactive components from both organic cation and anion exchange resin; two alternative leach methods were identified (Dodd 1998). The preferred method was to treat the mixed resin with $0.4 \underline{\mathrm{M}} \mathrm{Ce}(\mathrm{IV})$ in $6 \underline{\mathrm{M}} \mathrm{HNO}_{3}$. The strong acid would displace $\mathrm{Cs}, \mathrm{U}, \mathrm{Pu}$, and $\mathrm{Am}$ sorbed on the cation resin. In $6 \underline{\mathrm{M}} \mathrm{HNO}_{3}$, the Ce(IV) also would remove $\mathrm{Pu}$ from the anion resin by mass action displacement of the $\mathrm{Pu}(\mathrm{IV})$ complex by the analogous $\mathrm{Ce}(\mathrm{IV})$ complex and by oxidation of the $\mathrm{Pu}(\mathrm{IV})$ to $\mathrm{Pu}(\mathrm{VI})$. The $\mathrm{Pu}(\mathrm{VI})$ anionic nitrate complex, $\left[\mathrm{PuO}_{2}\left(\mathrm{NO}_{3}\right)_{4}\right]^{2-}$, is less strongly sorbed in $6 \mathrm{M} \mathrm{HNO}_{3}\left(\mathrm{~K}_{\mathrm{d}} \cong 4\right)$ than the $\mathrm{Pu}(\mathrm{IV})$ nitrate complex $\left(\mathrm{K}_{\mathrm{d}} \cong 1000\right)$.

The second proposed method for the mixed resin was to treat in two steps. The initial step would be exposure to strong ( $>3 \underline{\mathrm{M}}) \mathrm{HNO}_{3}$. This would displace the cations $(\mathrm{Cs}, \mathrm{U}, \mathrm{Pu}, \mathrm{Am})$ from the cation resin. The second step would use $0.1 \mathrm{M} \mathrm{HNO}_{3}$ with $0.2 \mathrm{M}$ oxalic acid to form the sufficiently soluble and charge-neutral $\left[\mathrm{Pu}\left(\mathrm{C}_{2} \mathrm{O}_{4}\right)_{2}\right]^{0}$ oxalate complex (Reas 1949). Acid exchanged from the resin (Donen effect) would increase the effective $\mathrm{HNO}_{3}$ concentration above the $0.1 \mathrm{M} \mathrm{HNO}_{3}$ added. Because the plutonium complex is uncharged, it would have little affinity for either the anion or cation resins and the plutonium would partition to the solution.

Laboratory tests were performed with the water-rinsed KES-H-08 IX materials alone and mixed with added sludge to simulate incomplete washing. The two-step nitric/oxalic acid treatment generally gave better overall solids decontamination than the Ce(IV) treatment (Delegard and Rinehart 1998). The presence of added sludge severely increased the concentrations of uranium, plutonium, and americium in the treated residues. However, the TRU concentrations in the residues were consistently lower for the nitric/oxalic treatment than for the $\mathrm{Ce}$ (IV) treatment. The better performance of nitric/oxalic was almost solely because of its better removal of plutonium for the tests both with and without added sludge. Comparison of the test data for the leachants also showed that better ${ }^{137} \mathrm{Cs}$ and ${ }^{241} \mathrm{Am}$ decontamination was obtained by leaching at higher acid concentrations. Other studies investigated the decontamination of residues produced by $\mathrm{HNO}_{3}$ treatment of $\mathrm{K}$ Basins sludge. Of the four candidate leachants studied, mixed $6 \underline{\mathrm{M}} \mathrm{HNO}_{3} / 0.3 \mathrm{M} \mathrm{HF}$ clearly gave the highest decontamination from uranium, plutonium, and americium and was nearly the best in decontamination from cesium (Delegard et al. 1998).

Because of the improved ${ }^{137} \mathrm{Cs}$ and ${ }^{241} \mathrm{Am}$ removal from the IX materials at higher acid concentrations and the improved overall decontamination of dissolver residues afforded by $\mathrm{HNO}_{3} / \mathrm{HF}$, additional leach testing of IX materials was proposed. The $6 \mathrm{MHNO}_{3} / 0.3 \mathrm{M} \mathrm{HF}$ leachant would be used in the first step.

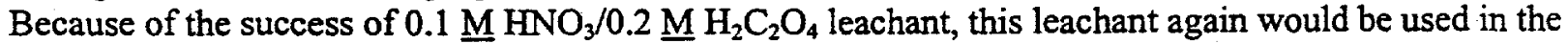
second step. 
Results of tests of DX materials both with and without added sludge using the revised two-step leach method are described and reported. 


\subsection{Experimental Materials and Methods}

All testing and analyses were performed in the Radiochemical Processing Laboratory (RPL). Approved Test Instructions were followed to perform the leach contact tests and to separate the IX materials into OIER and Zeolon-900 fractions; analyses followed approved analytical procedures. The leach contacts were made in the RPL shielded analytical laboratory hot cell facility.

\subsection{Materials}

Materials taken from the characterized and sieved KES-H-08 (H-08) KE Basin sample again were used as the IX material in these tests. This material is identical, except for some incidental drying, to the material used in the prior testing of IX material leaching (Delegard and Rinehart 1998). As described in the previous report, the $\mathrm{H}-08$ material was rinsed of adsorbed sludge particles. In the rinse procedure, portions of the as-received H- 08 sample were placed on a Tyler 42 sieve ( $346 \mu \mathrm{m}$ mesh opening). Distilled and deionized (DI) water was flowed over each portion by use of a plastic squirt bottle. The washed IX material showed cation resin (dark), and anion resin (amber-colored), and white Zeolon-900 grains. The rinse waters were turbid. Very little resin passed through the sieve but some brown irregular-shaped granules were found. The rinsed material's appearance was identical to that of IX materials prepared in earlier tests (Figure 2.1 in Schmidt et al. 1999). The solids were drained on the sieve and the rinsed portions collected in a single jar. The rinsed material was designated $\mathrm{H}-08 \mathrm{BEAD}$ $\mathrm{G}$, and two sample aliquots were taken for analysis (analysis results in Delegard and Rinehart 1998).

Further characterizations of the IX materials were performed in this study. The objective was to determine the distribution of the radioelements of interest (cesium, uranium, plutonium, and americium) to the separate OIER and Zeolon-900 fractions. Separations were performed for the as-received H-08 and the water-rinsed H-08 BEAD G materials. The separation was performed on the air-dried materials. Portions of the IX materials were placed in a plastic $15-\mathrm{cm}$ square weighing boat. The weighing boat had a $1-\mathrm{cm}$ hole punched through one corner. With gentle shaking and tilting of the weighing boat, the spherical OIER beads were rolled away from the granular Zeolon-900 and other irregular solids. The separated beads dropped through the hole in the weighing boat and were collected in an intact weighing boat placed under the hole. The granular solids left behind also were collected. By this technique, relatively clean OIER and Zeolon-900 fractions were obtained. Some cross-contamination was inevitable, however. The granular fraction visibly contained hemispherical bead pieces that did not roll; fine powders adhered to the OIER beads as shown by scanning electron microscopy. The separated fractions were analyzed.

The sludge that was added in two of the present experiments was the same sludge as used in the prior tests (KECOMP) except for some incidental drying (Delegard and Rinehart 1998). This material is a composite of canister sludges taken from the KE Basin.

Leach solutions were prepared using DI water and reagent-grade chemicals: crystalline oxalic acid $\left(\mathrm{H}_{2} \mathrm{C}_{2} \mathrm{O}_{4} \cdot 2 \mathrm{H}_{2} \mathrm{O}\right), 29 \mathrm{M}$ hydrofluoric acid $(\mathrm{HF})$, and $15.9 \mathrm{M}$ nitric acid $\left(\mathrm{HNO}_{3}\right)$ solution. Reagents were prepared quantitatively ( \pm 0.0001 gram) using a Mettler AE 240 balance, calibrated pipets, and volumetric glassware. 


\subsection{Leaching Experimental Procedure}

Four leach tests were performed. First, 1-gram aliquots of rinsed resin (H-08 BEAD G) were weighed $( \pm 0.0001 \mathrm{gram})$ into four tare-weighed $15-\mathrm{mL}$ capped polystyrene centrifuge cones. To one of the cones (test RESIN 3), $\sim 0.04$ grams of sludge sample KECOMP was added and the weight ( \pm 0.0001 gram) measured. To another cone (RESIN 4), about 0.01 grams of KECOMP was added. The KECOMP material, a composite of KE Basin canister sludge samples, was characterized for radioelement concentrations in separate testing. The test matrix, weights of $\mathrm{H}-08$ BEAD G and KECOMP materials used in the individual tests, and the respective leachants are described in Table 1. The quantities used in prior analogous tests (OIER 5 though OIER 8) are presented for later comparison. Note that the amounts of IX material (dry weight basis) were lower in the previous tests (Delegard and Rinehart 1998). This is because the IX material was much wetter in the prior tests, containing about $46.4-\mathrm{wt} \%$ water.

Table 1. Leachants and Material Weights in Present and Prior Leach Testing

\begin{tabular}{|c|c|c|c|c|}
\hline \multirow[b]{2}{*}{ Test } & \multicolumn{2}{|c|}{ Leachant } & \multicolumn{2}{|c|}{ Material Mass, dry basis, $g$} \\
\hline & First Leach & Second Leach & $\overline{\mathrm{H}-08 \mathrm{BEAD} G}$ & KECOMP \\
\hline OIER 5 & $4 \mathrm{M} \mathrm{HNO}_{3}$ & $0.1 \mathrm{M} \mathrm{FNO}_{3} /$ & 0.4530 & 0 \\
\hline OIER 6 & & $0.2 \underline{\mathrm{M}} \mathrm{H}_{2} \mathrm{C}_{2} \mathrm{O}_{4}$ & 0.5757 & 0 \\
\hline OIER 7 & & & 0.4749 & 0.0235 \\
\hline OIER 8 & & & 0.5409 & 0.0419 \\
\hline RESNN 1 & $6 \mathrm{M} \mathrm{HNO}_{3} /$ & $0.1 \mathrm{M} \mathrm{HNO}_{3} /$ & 0.9401 & 0 \\
\hline RESIN 2 & $0.3 \mathrm{M}$ HF & $0.2 \overline{\mathrm{M}} \mathrm{H}_{2} \mathrm{C}_{2} \mathrm{O}_{4}$ & 0.9806 & 0 \\
\hline RESIN 3 & & & 1.1371 & 0.0345 \\
\hline$\overline{\text { RESIN } 4}$ & & & 0.9331 & 0.0060 \\
\hline
\end{tabular}

As in the prior tests, all leach contacts of the IX material or IX material with sludge were conducted at ambient hot cell temperature $\left(-28^{\circ} \mathrm{C}\right)$ with 4-hour contact times and $5 \mathrm{~mL}$ of leachant. The test centrifuge cones were agitated every 15 minutes to achieve mixing. After 4 hours of contact with the first leachant ( $6 \underline{\mathrm{M} \mathrm{HNO}} \mathrm{HN}_{3} / 0.3 \mathrm{M} \mathrm{HF}$ ), the solution was removed from the solids by centrifugation and decantation by transfer pipet. The solutions were withdrawn by placing the pipet tip at the centrifuge cone bottom and carefully suctioning the solution. This technique essentially drained the interstitial liquid from the resin. The solids were washed, centrifuged, and decanted by pipet in the same manner in their respective centrifuge cones with two $1-\mathrm{mL}$ aliquots of $6 \mathrm{M} \mathrm{HNO} / 0.3 \mathrm{M}$ HF. The washes were added to the original leachate. The second leachant $\left(0.1 \mathrm{M} \mathrm{HNO} / 0.2 \mathrm{M} \mathrm{H}_{2} \mathrm{C}_{2} \mathrm{O}_{4}\right)$ then was added to the solids. After 4 hours of contact, the solids were separated from the solution by vacuum filtration and washed on the filters three times with $1-\mathrm{mL}$ aliquots of fresh leachant $\left(0.1 \mathrm{M} \mathrm{HNO} / 0.2 \mathrm{M} \mathrm{H}_{2} \mathrm{C}_{2} \mathrm{O}_{4}\right)$. The washes were added to the second leachate. The washed solids were weighed, dried at $105^{\circ} \mathrm{C}$, and reweighed in preparation for analysis. The two leachates with contained rinses for each test also were weighed and collected for analysis. 


\subsection{Analyses}

The radiochemical analyses were performed in the RPL analytical laboratory using established procedures.

In the previous tests (Delegard and Rinehart 1998), two portions of the moist H-08 BEAD G were analyzed to determine concentrations of uranium, radionuclides $\left({ }^{241} \mathrm{Am},{ }^{239,240} \mathrm{Pu},{ }^{238} \mathrm{Pu}\right.$, and $\left.{ }^{137} \mathrm{Cs}\right)$, and water. The solids also were analyzed to determine bulk metal concentrations by inductively coupled plasma - atomic energy spectrometry (ICP-AES). Water concentration was determined by measuring the mass loss caused by drying weighed solids aliquots in an oven overnight at $105^{\circ} \mathrm{C}$. Analytical results for the sludge material, KECOMP, also were reported previously (Delegard and Rinehart 1998). In the present tests, the water contents of H-08 BEAD G and KECOMP were again determined by oven drying. The water concentration data and the prior radiochemical and ICP-AES results were combined to determine the quantities of uranium and radionuclides in the IX material aliquots used in the leach testing.

The separated OIER and Zeolon-900 fractions of the as-received $\mathrm{H}-08$ and $\mathrm{H}-08 \mathrm{BEAD}$ G were also analyzed. The air-dried fractions were digested by fusion in molten $\mathrm{KOH} / \mathrm{KNO}_{3}$ followed by acid dissolution. The fused and dissolved materials were analyzed for uranium concentration by timeresolved laser fluorimetry, ${ }^{137} \mathrm{Cs}$ and ${ }^{241} \mathrm{Am}$ concentrations by gamma energy analyses (GEA), and total alpha, ${ }^{239,240} \mathrm{Pu}$, and ${ }^{238} \mathrm{Pu} /{ }^{241} \mathrm{Am}$ concentrations by alpha energy analyses (AEA). The digested fractions also were analyzed to determine metal concentrations by ICP-AES.

The residual solids remaining from the four leach tests were digested by fusion in molten $\mathrm{KOH} / \mathrm{KNO}_{3}$ followed by acid dissolution in the same manner as the H-08 BEAD G material. The digestates were analyzed for uranium, ${ }^{137} \mathrm{Cs}$, ${ }^{241} \mathrm{Am}$, total alpha, ${ }^{239,240} \mathrm{Pu}$, and ${ }^{238} \mathrm{Pu} /{ }^{241} \mathrm{Am}$ concentrations. Similarly, the leachates were analyzed to determine uranium, ${ }^{137} \mathrm{Cs},{ }^{241} \mathrm{Am}$, total alpha, ${ }^{239,240} \mathrm{Pu}$, and ${ }^{238} \mathrm{Pu} /{ }^{241} \mathrm{Am}$ concentrations by the same analytical techniques as used for the digested solids.

The ${ }^{241}$ Am concentrations also were determined by alpha AEA by deducting the expected ${ }^{238} \mathrm{Pu}$ activity $\left(0.15\right.$ of the ${ }^{239,240} \mathrm{Pu}$ activity) from the ${ }^{238} \mathrm{Pu} /{ }^{241} \mathrm{Am}$ AEA peak. The counting statistics generally were much better for the AEA than for the GEA. For this reason, the ${ }^{241} \mathrm{Am}$ results derived in this manner from the AEA data (confirmed by the ${ }^{241}$ Am GEA data) were used in all calculations. 


\subsection{Experimental Results and Discussion}

Experimental observations of the qualitative behavior and radiochemical distributions in the leach testing are presented and interpreted.

\subsection{Qualitative Observations}

Photographs of the separated resin and inorganic fractions from sample H-08 (as-received) and the water-rinsed H-08 BEAD G IX materials are shown in Figures 1 and 2, respectively. A scanning electron photomicrograph of H-08 BEAD G LX material is shown, with observations, in Figure 3 . The separations were not perfect with inorganic particles clearly visible in the resin fractions and resin hemispheres found in the inorganic fractions. The resin fractions show both the amber (anion) and darkcolored (cation) beads. The inorganic fraction shows the white- to tan-colored Zeolon-900 particles.

Bubbling was observed upon contact of the H-08 BEAD G, with or without added KECOMP sludge, with the $6 \mathrm{M} \mathrm{HNO}_{3} / 0.3 \underline{\mathrm{M}} \mathrm{HF}$ leachant. No bubbling at all was observed with the second contact leachant, $0.1 \underline{\mathrm{M} \mathrm{HNO}} \mathrm{HN}_{3} / 2 \mathrm{M} \mathrm{H}_{2} \mathrm{C}_{2} \mathrm{O}_{4}$.

Much of the amber-colored anion exchange resin was observed to float in the $6 \underline{\mathrm{M}} \mathrm{HNO}_{3} / 0.3 \underline{\mathrm{M}} \mathrm{HF}$ leachant, even after 4 hours contact. Some flotation was caused by adhesion of bubbles on the resin. However, agitation to disengage the bubbles sunk some, but not all, of the floating resin. No resin floated in tests with $0.1 \underline{\mathrm{M} \mathrm{HNO}} 3 / 0.2 \mathrm{M} \mathrm{H}_{2} \mathrm{C}_{2} \mathrm{O}_{4}$. Neither the dark-colored cation resin nor the zeolite granules floated in any test.

Tests with added sludge (RESIN 3 and 4) produced turbid solutions; solutions from tests RESIN 1 and 2 without added sludge were relatively clear.

\subsection{Analyses and Composition of Starting Materials}

Results of the chemical and radiochemical analyses of the rinsed resin-bearing material (H-08 BEAD G) and the KECOMP sludge material used as starting materials in these tests are given in Table 2. Many of these data were presented previously (Delegard and Rinehart 1998). Also given in Table 2 are the water concentrations in the H-08 BEAD G and KECOMP materials determined for the present tests. The quantities of radiochemicals present in each RESIN test (bottom, Table 2) were calculated based on the weights of the wet starting solids (Table 1) and the solids concentration data. The analytical data show the KECOMP sludge to be about 300 times more concentrated in uranium than the washed $\mathrm{H}-08 \mathrm{BEAD}$ $\mathrm{G}$ and 700 to 600 times more concentrated in plutonium and americium. However, the KECOMP sludge is only about 8 times more concentrated in ${ }^{137} \mathrm{Cs}$, indicating the extensive (and expected) cesium loading on the resin and zeolite solids. Also presented for comparison in Table 2 are the quantities of radiochemicals present in the analogous OIER tests number 5 through 8.

Analytical results of the separated organic (resin beads) and inorganic (zeolite) fractions of the asreceived $\mathrm{H}-08$ and the water-rinsed $\mathrm{H}-08 \mathrm{BEAD}$ G materials are given in Table 3. The concentrations of the combined resin and inorganic fractions were calculated using the silicon concentration previously determined for $\mathrm{H}-08 \mathrm{BEAD} \mathrm{G}(86,200 \mu \mathrm{g} \mathrm{Si} / \mathrm{g}$ dry solid $)$ as the normalization reference. The 
concentrations found for the combined fractions of the as-received $\mathrm{H}-08$ and the water rinsed $\mathrm{H}-08$ $\mathrm{BEAD} \mathrm{G}$ are compared in Table 3 with the concentrations found for the H-08 BEAD G reported previously (Delegard and Rinehart 1998).

Table 2. Radiochemical Concentrations and Quantities in the Starting Materials

\begin{tabular}{|c|c|c|c|c|c|c|}
\hline \multirow[b]{2}{*}{ Solid } & \multicolumn{6}{|c|}{ Concentration in Dry Solids ${ }^{2}$} \\
\hline & $\begin{array}{l}{ }^{137} \mathrm{Cs}, \\
\mu \mathrm{Ci} / \mathrm{g}\end{array}$ & $\begin{array}{c}\mathrm{U} \\
\mu \mathrm{g} / \mathrm{g}\end{array}$ & $\begin{array}{c}{ }^{239,240} \mathrm{Pu} \\
\mu \mathrm{Ci} / \mathrm{g}\end{array}$ & $\begin{array}{l}{ }^{241} \mathrm{Am}, \\
\mu \mathrm{Ci} / \mathrm{g}\end{array}$ & $\begin{array}{c}{ }^{238} \mathrm{Pu}{ }^{241} \mathrm{Am} \\
\mu \mathrm{Ci} / \mathrm{g}\end{array}$ & $\begin{array}{c}\text { Total Alpha, } \\
\mu \mathrm{Ci} / \mathrm{g}\end{array}$ \\
\hline $\mathrm{H}-08 \mathrm{BEAD} \mathrm{G}$ & 103 & 2180 & 0.168 & 0.148 & 0.186 & 0.362 \\
\hline KECOMP Sludge & 809 & 685000 & 120.7 & 95.3 & 99.7 & 220.4 \\
\hline \multirow[b]{2}{*}{ Test } & \multicolumn{6}{|c|}{ Calculated Quantity in Test } \\
\hline & $\mu \mathrm{Ci}$ & $\mu \mathrm{g}$ & $\mu \mathrm{Ci}$ & $\mu \mathrm{Ci}$ & $\mu \mathrm{Ci}$ & $\mu \mathrm{Ci}$ \\
\hline OIER 5 & 46 & 989 & 0.076 & 0.067 & 0.084 & 0.164 \\
\hline OIER 6 & 59 & 1260 & 0.097 & 0.085 & 0.107 & 0.209 \\
\hline OIER 7 & 68 & 17200 & 2.92 & 2.32 & 2.44 & 5.40 \\
\hline OEER 8 & 89 & 29900 & 5.15 & 4.08 & 4.28 & 9.51 \\
\hline RESIN 1 & 96 & 2050 & 0.158 & 0.139 & 0.175 & 0.341 \\
\hline RESIN 2 & 101 & 2140 & 0.165 & 0.145 & 0.183 & 0.355 \\
\hline RESIN 3 & 145 & 26100 & 4.37 & 3.46 & 4.13 & 8.51 \\
\hline RESIN 4 & 101 & 6120 & 0.879 & 0.707 & 0.851 & 1.74 \\
\hline
\end{tabular}

Table 3. Concentrations in Dry Solids

\begin{tabular}{|c|c|c|c|c|c|c|}
\hline \multirow[b]{2}{*}{ Solid (fraction in combined) } & \multicolumn{6}{|c|}{ Element Concentrations, $\mu \mathrm{g} / \mathrm{g}$} \\
\hline & $\overline{\mathrm{Al}}$ & $\overline{\mathrm{Ca}}$ & $\mathrm{Fe}$ & $\mathrm{Na}$ & $\overline{\mathrm{Si}}$ & $\overline{\mathrm{U}}$ \\
\hline $\mathrm{H}-08, \mathrm{resin}(0.546)$ & 4930 & 14200 & 1550 & 34700 & 2400 & 1840 \\
\hline $\mathrm{H}-08$, inorg. $(0.454)$ & 45600 & 6230 & 18100 & 27900 & 187000 & 1490 \\
\hline $\mathrm{H}-08 \mathrm{BEAD} \mathrm{G}, \mathrm{resin}(0.636)$ & 4430 & 12200 & 1320 & 30200 & 4510 & 2020 \\
\hline H-08 BEAD G, inorg. (0.364) & 46900 & 5370 & 11200 & 27800 & 229000 & 488 \\
\hline H-08, combined $^{2}$ & 23400 & 10600 & 9060 & 31600 & 86200 & 1680 \\
\hline H-08 BEAD G, combined ${ }^{2}$ & 19900 & 9680 & 4920 & 29300 & 86200 & 1460 \\
\hline H-08 BEAD G & 23600 & 20100 & 7630 & 55900 & 86200 & 2180 \\
\hline \multirow[b]{2}{*}{ Solid } & \multicolumn{6}{|c|}{ Radionuclide Concentrations, $\mu \mathrm{Ci} / \mathrm{g}$} \\
\hline & ${ }^{60} \mathrm{Co}$ & ${ }^{137} \mathrm{Cs}$ & $239,240 \mathrm{Pu}$ & ${ }^{241} \mathrm{Am}$ & ${ }^{238} \mathrm{Pu} /{ }^{241} \mathrm{Am}$ & Total $\alpha$ \\
\hline $\mathrm{H}-08$, resin & 0.0433 & 8.36 & 0.138 & 0.168 & 0.189 & 0.329 \\
\hline H-08, inorg. & 0.0467 & 371 & 0.558 & 0.338 & 0.422 & 0.986 \\
\hline $\mathrm{H}-08 \mathrm{BEAD} \mathrm{G}$, resin & 0.0432 & 7.34 & 0.113 & 0.140 & 0.156 & 0.272 \\
\hline $\mathrm{H}-08$ BEAD G, inorg. & 0.0275 & 496 & 0.454 & 0.248 & 0.316 & 0.773 \\
\hline \begin{tabular}{|c|} 
H-08, combined ${ }^{2}$ \\
\end{tabular} & 0.0448 & 173 & 0.329 & 0.245 & 0.295 & 0.627 \\
\hline H-08 BEAD G, combined ${ }^{2}$ & 0.0375 & 185 & 0.237 & 0.179 & 0.215 & 0.455 \\
\hline H-08 BEAD G & 0.0403 & 103 & 0.168 & 0.148 & 0.186 & 0.362 \\
\hline
\end{tabular}


As shown in Table 3, both the total alpha and the combined ${ }^{238,239,240} \mathrm{Pu}$ and ${ }^{241} \mathrm{Am}$ concentrations in the washed and dry resin-bearing material, $\mathrm{H}-08 \mathrm{BEAD} \mathrm{G}$, are about $0.36 \mu \mathrm{Ci}$ per gram. The concentrations derived from combining the resin ( 0.636 weight fraction) and inorganic $(0.364 \mathrm{wt}$ fraction) portions of $\mathrm{H}-08 \mathrm{BEAD} \mathrm{G}$ are somewhat higher at about $0.45 \mu \mathrm{Ci}$ per gram. The TRU concentrations in the asreceived $\mathrm{H}-08$ resin ( $0.546 \mathrm{wt}$ fraction) and inorganic ( $0.454 \mathrm{wt}$ fraction) portions are about $0.63 \mu \mathrm{Ci} / \mathrm{g}$, similar to the concentrations, 0.65 to $0.84 \mu \mathrm{Ci} / \mathrm{g}$, found in previous scoping tests (Schmidt et al. 1999). The water rinsing evidently removed about $1 / 3$ of the TRU (Pu and Am) activity. A corresponding decrease in iron concentration with water rinșing also is observed and may be correlated.

Water rinsing did not significantly alter the inorganic/resin concentration distributions for the bulk elements $\mathrm{Al}, \mathrm{Ca}, \mathrm{Na}$, and $\mathrm{Si}$. Water rinsing also did not change iron and uranium concentrations in the resin fractions. However, water rinsing decreased both iron and uranium concentrations in the inorganic fractions, indicating the presence of finely particulate iron- and uranium-rich solids. Water rinsing decreased the iron concentration in the inorganic fraction about $1 / 3$ and decreased the uranium concentration about $2 / 3$.

Even more interesting are the individual elements' distributions on the resin and inorganic fractions. The success in separating the resin and inorganic fractions can be appraised by comparing the silicon concentrations. It was expected that though some loading of silicic acid may occur on ion exchange resin, the loading should be small. Indeed, that was the case. The silicon concentrations in the resin fractions were 1 to $2 \%$ of the concentrations found in the inorganic fraction and probably reflect the collection of incidental rounded inorganic materials with the resin beads. Iron and aluminum, which both form poorly soluble (hydr)oxides in $\mathrm{pH}$-neutral water, were about 10-times more concentrated in the inorganic fraction than in the resin. Sodium and calcium were both somewhat more concentrated in the resin than in the inorganic solids. This may indicate preferential uptake of the soluble cations on the resin. Uranium sorption on the resin also is indicated with uranium about 4-times more concentrated on the water-rinsed resin than in the water-rinsed inorganic (principally zeolite) fraction.

Except for ${ }^{60} \mathrm{Co}$ (which was about equally concentrated in the inorganic and resin fractions), radionuclide concentrations were higher in the inorganic fraction than in the resin. Thus, ${ }^{239,240} \mathrm{Pu}$ was about 4-times more concentrated in the inorganic fraction, and ${ }^{241} \mathrm{Am}$ about 2-times more concentrated. For ${ }^{137} \mathrm{Cs}$, the difference was striking with the inorganic (zeolite) fraction being about 50-times more concentrated than the resin. Decontamination of the IX materials of ${ }^{137} \mathrm{Cs}$ clearly must target the zeolite.

\subsection{Leachate Analyses}

The concentrations of radioelements found in the combined leachates and rinses from the first and second leach contacts are presented in Table 4. The concentration data in the replicate tests (RESIN 1 and 2) generally compare well in light of the quantities of starting material. Leachates from the RESIN 3 and 4 tests are more concentrated (RESIN $3>$ RESIN 4 ) because of the presence and amount of added sludge. 
Table 4. Radiochemical Concentrations in Test Leachates

\begin{tabular}{|c|c|c|c|c|c|c|c|c|c|c|c|c|}
\hline \multirow[b]{3}{*}{ Test } & \multicolumn{12}{|c|}{ Concentrations in $1^{\text {st }}$ and $2^{\text {nd }}$ Contacts } \\
\hline & \multicolumn{2}{|c|}{$\begin{array}{c}{ }^{137} \mathrm{Cs}, \\
\mu \mathrm{Ci} / \mathrm{mL}\end{array}$} & \multicolumn{2}{|c|}{$\begin{array}{c}\mathrm{U} \\
\mu \mathrm{g} / \mathrm{mL}\end{array}$} & \multicolumn{2}{|c|}{$\begin{array}{l}{ }^{239,240} \mathrm{Pu} \\
\mu \mathrm{Ci} / \mathrm{mL}\end{array}$} & \multicolumn{2}{|c|}{$\begin{array}{c}{ }^{241} \mathrm{Am} \\
\mu \mathrm{Ci} / \mathrm{mL}^{\mathrm{a}}\end{array}$} & \multicolumn{2}{|c|}{$\begin{array}{c}{ }^{238} \mathrm{Pu} /{ }^{241} \mathrm{Am} \\
\mu \mathrm{Ci} / \mathrm{mL}\end{array}$} & \multicolumn{2}{|c|}{$\begin{array}{l}\text { Total } \alpha \\
\mu \mathrm{Ci} / \mathrm{mL}\end{array}$} \\
\hline & $1^{s t}$ & $2^{\text {nd }}$ & $1^{\text {st }}$ & $2^{\text {nd }}$ & $1^{\text {st }}$ & $2^{\text {nd }}$ & $1^{\text {st }}$ & $2^{\text {nd }}$ & $1^{\mathrm{st}}$ & $2^{\text {nd }}$ & $1^{\text {st }}$ & $2^{\text {nd }}$ \\
\hline RESIN 1 & 7.17 & 0.646 & 187 & 119 & 0.0119 & 0.0211 & 0.0212 & 0.0058 & 0.0230 & 0.00907 & 0.0351 & 0.0310 \\
\hline RESIN 2 & 8.28 & 0.931 & 189 & 123 & 0.0108 & 0.0199 & 0.0222 & 0.0097 & 0.0239 & 0.0128 & 0.0351 & 0.0339 \\
\hline RESIN 3 & 10.1 & 2.44 & 1930 & 2100 & 0.104 & 0.296 & 0.225 & 0.0375 & 0.241 & 0.0829 & 0.345 & 0.386 \\
\hline RESIN 4 & 7.39 & 1.06 & 645 & 949 & 0.0352 & 0.141 & 0.0871 & 0.0040 & 0.0925 & 0.0256 & 0.128 & 0.167 \\
\hline
\end{tabular}

\subsection{Leach Residue Analyses}

The radiochemical concentrations in the leach residues are given in Table 5. The concentrations are compared with concentrations found in previous tests using two-step leaching with $4 \underline{\mathrm{M}} \mathrm{HNO}_{3}$ (versus $6 \underline{\mathrm{M} \mathrm{HNO}} \mathrm{HN}_{3} / 0.3 \underline{\mathrm{M}} \mathrm{HF}$ in the present tests) followed by $0.1 \underline{\mathrm{M} \mathrm{HNO}} 3 \mathrm{HN}_{3} / 2 . \mathrm{M} \mathrm{H}_{2} \mathrm{C}_{2} \mathrm{O}_{4}$ (same as present tests). The final residue weights also given in Table 5 show (by comparison with Table 1) that 10 to $20 \%$ IX material weight loss occurred by the leach treatment. The weight data also show that, though both the RESIN and OIER test series started with about 1 gram of wet IX material, the RESIN tests used about 2-times more IX material than the OIER tests on a dry basis. This is because the IX material dried between the OIER and RESIN tests.

Table 5. Radiochemical Concentrations in Test Residues

\begin{tabular}{|c|c|c|c|c|c|c|c|}
\hline \multirow[b]{2}{*}{ Test } & \multicolumn{6}{|c|}{ Concentration } & \multirow{2}{*}{$\begin{array}{c}\text { Final } \\
\text { Weight, } \\
\text { g }\end{array}$} \\
\hline & $\begin{array}{l}{ }^{137} \mathrm{Cs}, \\
\mu \mathrm{Ci} / \mathrm{g}\end{array}$ & $\begin{array}{c}\mathrm{U}, \\
\mu \mathrm{g} / \mathrm{g}\end{array}$ & $\begin{array}{c}{ }^{239,240} \mathrm{Pu} \\
\mu \mathrm{Ci} / \mathrm{g}\end{array}$ & $\begin{array}{l}{ }^{241} \mathrm{Am} \\
\mu \mathrm{Ci} / \mathrm{g}^{\mathrm{a}}\end{array}$ & $\begin{array}{c}{ }^{238} \mathrm{Pu} /{ }^{241} \mathrm{Am} \\
\mu \mathrm{Ci} / \mathrm{g}\end{array}$ & $\begin{array}{c}\text { Total } \alpha, \\
\mu \mathrm{Ci} / \mathrm{g}\end{array}$ & \\
\hline OIER 5 & 35.9 & 920 & 0.0210 & 0.0814 & 0.0846 & 0.102 & 0.3687 \\
\hline OIER 6 & $\overline{42.4}$ & 1140 & 0.0242 & 0.0886 & 0.0923 & 0.121 & 0.5021 \\
\hline OIER 7 & 98.7 & 3490 & 0.152 & 0.992 & 1.000 & 1.120 & 0.3894 \\
\hline OIER 8 & 68.6 & 7080 & 0.289 & 1.750 & 1.670 & 1.830 & 0.4435 \\
\hline RESIN 1 & 30.8 & 478 & 0.0141 & 0.0669 & 0.0691 & 0.0882 & 0.7557 \\
\hline RESIN 2 & 37.0 & 455 & 0.0138 & 0.0724 & 0.0745 & 0.0947 & 0.7915 \\
\hline RESIN 3 & 25.6 & 10600 & 0.357 & 1.290 & 1.340 & 1.700 & 0.9127 \\
\hline RESIN 4 & 54.4 & 3400 & 0.0902 & 0.657 & 0.671 & 0.765 & 0.7787 \\
\hline
\end{tabular}

The ${ }^{137} \mathrm{Cs}$ concentrations in the residual IX material RESIN solids range from about 26 to $54 \mu \mathrm{Ci} / \mathrm{g}$ (or $\mu \mathrm{Ci} / \mathrm{mL}$ assuming a $1.0-\mathrm{g} / \mathrm{mL}$ bulk density of the largely resin residue). The ERDF criterion $(32 \mu \mathrm{Ci} / \mathrm{mL})$ is exceeded no more than 2 -fold for ${ }^{137} \mathrm{Cs}$ in the tests with added sludge and were near the ERDF criterion for the tests without added sludge. The OIER tests showed slightly higher ${ }^{137} \mathrm{Cs}$ 
concentrations in the residual solids than their RESIN test counterparts, especially for the tests with added sludge.

The TRU (total alpha) concentrations in the residues from tests without added sludge were near the ERDF $100-\mathrm{nCi} / \mathrm{g}$ limit for both RESIN and OIER tests. With added sludge, the ERDF TRU criterion was exceeded 8- to 18-fold. The TRU concentrations in the residues both with and without added sludge were slightly lower for the RESIN test residues than for the OIER test residues.

The plutonium concentrations in the residues from tests without added sludge (RESIN 1 and 2 and OIER 5 and 6) were below the equivalent ERDF plutonium criterion of $0.044 \mu \mathrm{Ci}^{239,240} \mathrm{Pu} / \mathrm{g}$. The ${ }^{239,240} \mathrm{Pu}$ limit is exceeded about 2 - to 8-fold for the residues from tests containing the added sludge. The ${ }^{239,240} \mathrm{Pu}$ concentrations in the RESIN test residues without sludge were about $1 / 3$ less concentrated than found for the analogous OIER IX material residues.

Americium concentrations in the residues were about 1.8-times the $50-\mathrm{nCi} / \mathrm{mL}$ ERDF limit in the tests without added sludge and up to 35 times the ERDF limit in the tests with sludge. Again, the RESIN test residues had slightly lower concentrations.

The ERDF criterion for uranium $(2,600 \mu \mathrm{g} / \mathrm{g}$ for the $1-\mathrm{g} / \mathrm{mL}$-density solids) were exceeded by a factor of 1.5 to 4 for the tests having added sludge; the tests without sludge were about 0.2 - to 0.5 -times the ERDF limit. The RESIN experiments gave lower residue uranium concentrations for the tests without added sludge.

Overall, the treatment used for the RESIN tests $\left(6 \underline{\mathrm{M} \mathrm{HNO}} \mathrm{HN}_{3} / 0.3 \underline{\mathrm{M}} \mathrm{HF}\right.$ followed by $0.1 \underline{\mathrm{M}} \mathrm{HNO}_{3} / 0.2 \underline{\mathrm{M}}$ $\mathrm{H}_{2} \mathrm{C}_{2} \mathrm{O}_{4}$ ) gave slightly better residual solid IX material decontamination compared with the treatment used with the OIER tests $\left(4 \mathrm{M} \mathrm{HNO}_{3}\right.$ followed by $\left.0.1 \underline{\mathrm{M}} \mathrm{HNO}_{3} / 0.2 \mathrm{M} \mathrm{H}_{2} \mathrm{C}_{2} \mathrm{O}_{4}\right)$. Improvements were greatest for ${ }^{137} \mathrm{Cs}$. However, for the key TRU constituents, ${ }^{239,240} \mathrm{Pu}$ and ${ }^{241} \mathrm{Am}$, the enhancements provided by the higher acid concentration and HF in the first leach contact of the RESIN tests were marginal. Clearly, the presence of added sludge has the most serious effect on meeting the ERDF criteria.

\subsection{Material Balances}

The radiochemical material balances for the RESIN leach tests are given in Tables 6 through 11 for ${ }^{137} \mathrm{Cs}, \mathrm{U},{ }^{239,240} \mathrm{Pu},{ }^{241} \mathrm{Am},{ }^{238} \mathrm{Pu} /{ }^{241} \mathrm{Am}$, and total alpha, respectively. The material balances compare the quantities of radiochemicals found in the weighed amounts of starting $\mathrm{K}$ Basin sludge materials (H-08 BEAD G and KECOMP) with the sum of the quantities found in the leach test fractions $\left(1^{\text {st }}\right.$ contact, $2^{\text {nd }}$ contact, and solids residue). The ratios of the sum of analyte found to the amount in the start, expressed as \% recovery, also are given in Tables 6 to 11 . Except for ${ }^{137} \mathrm{Cs}$ and most analytes for test RESIN 3, the amounts found in the leachates and residues exceeded the nominal quantities in the starting material. The discrepancies probably are rooted in sampling the heterogeneous and drying IX material and KECOMP sludge. 
Table 6. Leach Testing Material Balance for ${ }^{137} \mathrm{Cs}$

\begin{tabular}{|c|c|c|c|c|c|c|}
\hline \multirow{2}{*}{ Test } & \multicolumn{6}{|c|}{${ }^{137} \mathrm{Cs}, \mu \mathrm{Ci}$} \\
\cline { 2 - 7 } & Start & Sum & \% Recovery & $1^{\text {st }}$ Contact & $2^{\text {nd }}$ Contact & Residue \\
\hline RESIN 1 & 96.5 & 78.6 & 81.5 & 50.2 & 5.17 & 23.3 \\
\hline RESIN 2 & 101 & 94.7 & 94.1 & 58.0 & 7.45 & 29.3 \\
\hline RESIN 3 & 145 & 114 & 78.5 & 70.7 & 19.5 & 23.4 \\
\hline RESIN 4 & 101 & 103 & 102 & 51.7 & 8.48 & 42.4 \\
\hline
\end{tabular}

Table 7. Leach Testing Material Balance for Uranium

\begin{tabular}{|c|c|c|c|c|c|c|}
\hline \multirow{2}{*}{ Test } & \multicolumn{6}{|c|}{ Uranium, $\mu \mathrm{g}$} \\
\cline { 2 - 7 } & Start & Sum & \% Recovery & $1^{\text {st }}$ Contact & $2^{\text {nd }}$ Contact & Residue \\
\hline RESIN 1 & 2050 & 2620 & 128 & 1310 & 952 & 361 \\
\hline RESIN 2 & 2140 & 2670 & 125 & 1320 & 984 & 360 \\
\hline RESIN 3 & 26100 & 40000 & 153 & 13500 & 16800 & 9670 \\
\hline RESIN 4 & 6120 & 14800 & 241 & 4520 & 7592 & 2640 \\
\hline
\end{tabular}

Table 8. Leach Testing Material Balance for ${ }^{239,240} \mathrm{Pu}$

\begin{tabular}{|c|c|c|c|c|c|c|}
\hline \multirow{2}{*}{ Test } & \multicolumn{6}{|c|}{${ }^{239,240} \mathrm{Pu}, \mu \mathrm{Ci}$} \\
\cline { 2 - 7 } & Start & End & $\%$ Recovery & $1^{\text {st }}$ Contact & $2^{\text {nd }}$ Contact & Residue \\
\hline RESIN 1 & 0.158 & 0.263 & 166 & 0.0833 & 0.169 & 0.0107 \\
\hline RESIN 2 & 0.165 & 0.246 & 149 & 0.0756 & 0.159 & 0.0109 \\
\hline RESIN 3 & 4.370 & 3.420 & 78.3 & 0.728 & 2.370 & 0.326 \\
\hline RESIN 4 & 0.879 & 1.440 & 164 & 0.246 & 1.130 & 0.0702 \\
\hline
\end{tabular}

Table 9. Leach Testing Material Balance for ${ }^{241} \mathrm{Am}$

\begin{tabular}{|c|c|c|c|c|c|c|}
\hline \multirow{2}{*}{ Test } & \multicolumn{6}{|c|}{${ }^{241} \mathrm{Am}, \mu \mathrm{Ci}$} \\
\cline { 2 - 7 } & Start & End & \% Recovery & $1^{\text {st }}$ Contact & $2^{\text {nd }}$ Contact & Residue \\
\hline RESIN 1 & 0.139 & 0.246 & 176 & 0.148 & 0.0467 & 0.0506 \\
\hline RESIN 2 & 0.145 & 0.291 & 200 & 0.156 & 0.0780 & 0.0573 \\
\hline RESIN 3 & 3.460 & 3.050 & 88.1 & 1.580 & 0.300 & 1.170 \\
\hline RESIN 4 & 0.707 & 1.150 & 163 & 0.610 & 0.0318 & 0.512 \\
\hline
\end{tabular}

Table 10. Leach Testing Material Balance for ${ }^{238} \mathrm{Pu} /{ }^{241} \mathrm{Am}$

\begin{tabular}{|c|c|c|c|c|c|c|}
\hline \multirow{2}{*}{ Test } & \multicolumn{7}{|c|}{${ }^{238} \mathrm{Pu} /{ }^{241} \mathrm{Am}, \mu \mathrm{Ci}$} \\
\cline { 2 - 7 } & Start & End & $\%$ Recovery & $1^{\text {st }}$ Contact & $2^{\text {nd }}$ Contact & Residue \\
\hline RESIN 1 & 0.175 & 0.286 & 163 & 0.161 & 0.0726 & 0.522 \\
\hline RESIN 2 & 0.183 & 0.329 & 180 & 0.167 & 0.102 & 0.590 \\
\hline RESIN 3 & 4.130 & 3.570 & 86.5 & 1.690 & 0.663 & 1.220 \\
\hline RESIN 4 & 0.851 & 1.370 & 162 & 0.648 & 0.205 & 0.522 \\
\hline
\end{tabular}


Table 11. Leach Testing Material Balance for Total Alpha

\begin{tabular}{|c|c|c|c|c|c|c|}
\hline \multirow{2}{*}{ Test } & \multicolumn{6}{|c|}{ Total $\alpha, \mu \mathrm{Ci}$} \\
\cline { 2 - 7 } & Start & Sum & \% Recovery & $1^{\text {st }}$ Contact & $2^{\text {10 }}$ Contact & Residue \\
\hline RESIN 1 & 0.341 & 0.560 & 164 & 0.246 & 0.248 & 0.0667 \\
\hline RESIN 2 & 0.355 & 0.592 & 166 & 0.246 & 0.271 & 0.0750 \\
\hline RESIN 3 & 8.510 & 7.050 & 82.9 & 2.420 & 3.090 & 1.550 \\
\hline RESIN 4 & 1.740 & 2.830 & 163 & 0.896 & 1.340 & 0.596 \\
\hline
\end{tabular}

\subsection{Decontamination Factors}

The solids decontamination factors (DFs), based on dry solids weights, are shown in Table 12. The DF is the ratio of the concentration of the analyte of interest in the starting material to its concentration in the residue. The results from the prior related tests (OIER 5 through 8 ) are presented for comparison with the present RESIN 1 through 4 results. Direct comparison is somewhat tenuous because IX material drying caused the ratio of IX material to leachant to be about 2-fold higher in the RESIN test series than in the OIER series. As noted in the previous study (Delegard and Rinehart 1998), the results for test OIER 5 are questionable. The results are presented here for completeness.

Table 12. Decontamination Factors for Solids

\begin{tabular}{|c|c|c|c|c|c|c|}
\hline Test & ${ }^{137} \mathrm{Cs}$ & Uranium & ${ }^{239,240} \mathrm{Pu}$ & ${ }^{241} \mathrm{Am}$ & ${ }^{238} \mathrm{Pu} /{ }^{241} \mathrm{Am}$ & Total $\alpha$ \\
\hline OIER 5 & 2.5 & 4.8 & 16.2 & 4.6 & 5.1 & 8.0 \\
\hline OIER 6 & 1.9 & 2.4 & 6.3 & 2.4 & 2.6 & 3.3 \\
\hline OIER 7 & 1.5 & 12.1 & 43.0 & 5.0 & 5.5 & 10.8 \\
\hline OIER 8 & 2.1 & 10.0 & 38.2 & 4.5 & 5.5 & 10.8 \\
\hline RESIN 1 & 2.7 & 5.8 & 6.8 & 19.8 & 4.4 & 3.9 \\
\hline RESIN 2 & 2.6 & 6.0 & 6.4 & 18.2 & 4.5 & 4.1 \\
\hline RESIN 3 & 3.9 & 3.3 & 3.6 & 8.4 & 2.3 & 2.1 \\
\hline RESIN 4 & 2.0 & 4.7 & 4.0 & 17.2 & 2.2 & 1.9 \\
\hline 2 The OIER 5 results are questionable. \\
\hline
\end{tabular}

The primary objective of the present testing was to determine if the stronger acid (6 $\underline{M}$ versus $4 \underline{M}$ $\mathrm{HNO}_{3}$ ) and $0.3 \mathrm{M} \mathrm{HF}$ in the initial leach contact would be beneficial in decontaminating IX materials. For experiments without added sludge, the relative performances of the two approaches can be understood by comparing test results from OIER $6\left(4 \mathrm{M} \mathrm{HNO}_{3}\right)$ with those of the duplicate RESIN 1 and $2\left(6 \underline{\mathrm{M} \mathrm{HNO}} \mathrm{HN}_{3} / 0.3 \mathrm{M} \mathrm{HF}\right)$. For tests with added sludge, the OIER 7 and 8 results can be compared with the RESIN 3 and 4 results.

For the tests with only the well-rinsed IX material and without added sludge, the higher $\mathrm{HNO}_{3}$ concentration and added HF provided slightly superior decontamination from ${ }^{137} \mathrm{Cs}$ and uranium, 8-times better decontamination from ${ }^{241} \mathrm{Am}$, but no advantage in decontamination from ${ }^{239,240} \mathrm{Pu}$. The favorable results for ${ }^{137} \mathrm{Cs}$ and ${ }^{241} \mathrm{Am}$ were anticipated based on the earlier studies, which showed that higher acid concentrations displaced more of these radionuclides. 
In the tests with added sludge (OIER 7 and 8 and RESIN 3 and 4), the advantages incurred by higher $\mathrm{HNO}_{3}$ concentration and $\mathrm{HF}$ are retained, but to a lesser degree, for ${ }^{241} \mathrm{Am}$. The slight advantage for

${ }^{137} \mathrm{Cs}$ is also retained. However, decontamination from uranium and plutonium distinctly worsen.

\subsection{Distribution Coefficients}

Distribution coefficients $\left(\mathrm{K}_{\mathrm{d}} \mathrm{s}\right)$ are the ratios of the concentration of an analyte of interest in the solid phase, per gram, to the concentration of the analyte found in the equilibrium solution, per milliliter. The $\mathrm{K}_{\mathrm{d}} \mathrm{S}$ of the six analytes of interest for the prior tests OIER 5 through 8 and for the tests RESIN 1 through 4 are given in Table 13. The $K_{d} s$ are calculated on a dry solids basis. To calculate the $K_{d} s$ for the first contact, the quantity of activity on the solid phase after the first contact must be known. This quantity was taken to be the sum of the analyte contained in the second leach contact and in the final residue.

Table 13. Distribution Coefficients

\begin{tabular}{|c|c|c|c|c|c|c|c|}
\hline \multirow{2}{*}{$\begin{array}{c}1^{\text {st }} \text { Contact } \\
\text { Test }\end{array}$} & \multirow[b]{2}{*}{ Leachant } & \multicolumn{6}{|c|}{ Distribution Coefficient $\left(\mathrm{K}_{\mathrm{d}}\right), \mathrm{mL} / \mathrm{g}$} \\
\hline & & ${ }^{137} \mathrm{Cs}$ & Uranium & ${ }^{239,240} \mathrm{Pu}$ & ${ }^{241} \mathrm{Am}$ & ${ }^{238} \mathrm{Pu} /{ }^{241} \mathrm{Am}$ & Total $\alpha$ \\
\hline${\text { OIER } 5^{2}}^{2}$ & \multirow[t]{4}{*}{$4 \mathrm{MHNO}_{3}$} & 17 & 37 & 38 & 26 & 28 & 33 \\
\hline OIER 6 & & 16 & 22 & 9.4 & 8.9 & 8.9 & 8.8 \\
\hline OIER 7 & & 28 & 6.2 & 9.1 & 3.6 & 4.3 & 6.8 \\
\hline OIER 8 & & 13 & 5.0 & 6.7 & $\overline{3.5}$ & 3.7 & 5.7 \\
\hline$\overline{\text { RESNN } 1}$ & \multirow{4}{*}{$\begin{array}{l}6 \underline{\mathrm{M}} \mathrm{HNO}_{3} / \\
0.3 \mathrm{M} \mathrm{HF}\end{array}$} & 4.2 & $\overline{7.5}$ & 16 & 4.9 & $\overline{5.8}$ & 9.5 \\
\hline RESIN 2 & & 4.5 & $\overline{7.4}$ & 16 & 6.2 & 6.9 & 10 \\
\hline RESIN 3 & & 3.7 & 12 & 23 & 5.8 & 6.9 & 12 \\
\hline RESIN 4 & & $\overline{7.4}$ & 17 & 36 & 6.7 & 8.4 & 16 \\
\hline \multirow{2}{*}{$\mid \begin{array}{c}2^{\text {nd }} \\
\text { Contact } \\
\text { Test }\end{array}$} & \multirow[b]{2}{*}{ Leachant } & \multicolumn{6}{|c|}{ Distribution Coefficient $\left(\mathrm{K}_{\mathrm{d}}\right), \mathrm{mL} / \mathrm{g}$} \\
\hline & & ${ }^{137} \mathrm{Cs}$ & Uranium & ${ }^{239,240} \mathrm{Pu}$ & ${ }^{241} \mathrm{Am}$ & ${ }^{238} \mathrm{Pu} /{ }^{241} \mathrm{Am}$ & Total $\alpha$ \\
\hline 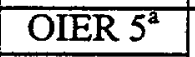 & \multirow{8}{*}{$\begin{array}{l}0.1 \underline{\mathrm{M}} \mathrm{HNO}_{3} / \\
0.2 \underline{\mathrm{M}} \mathrm{H}_{2} \mathrm{C}_{2} \mathrm{O}_{4}\end{array}$} & 32 & 5.2 & 1.2 & 6.5 & 5.6 & 2.8 \\
\hline OIER 6 & & 68 & 17 & 6.4 & 150 & 79 & 25 \\
\hline OIER 7 & & 87 & 4.9 & 0.8 & 190 & 39 & 5.3 \\
\hline OIER 8 & & 73 & 6.2 & 1.0 & 190 & 37 & 4.8 \\
\hline RESIN 1 & & 38 & 3.2 & 0.5 & 9.2 & 6.1 & 2.3 \\
\hline RESIN 2 & & 32 & 2.9 & 0.6 & 6.0 & 4.7 & 2.3 \\
\hline RESIN 3 & & 8.4 & 4.1 & 1.0 & 28 & 13 & 3.5 \\
\hline RESIN 4 & & 43 & 3.0 & 0.5 & 140 & 22 & 3.8 \\
\hline
\end{tabular}

The actinide $\mathrm{K}_{d} \mathrm{~s}$ for test OIER 5 are inaccurate. The results for OIER 6 (no added sludge) may be compared directly with those of RESIN 1 and 2 . It is seen in this comparison that cesium $\mathrm{K}_{d} \mathrm{~s}$ decrease, as expected, with increasing acid concentration in the first contact and are much higher in the low acid second contact. Americium $\mathrm{K}_{\mathrm{d}} \mathrm{s}$ are low for the first contact tests at $4 \underline{\mathrm{M}} \mathrm{HNO}_{3}$ or $6 \underline{\mathrm{M}} \mathrm{HNO}_{3} / 0.3 \underline{\mathrm{M}} \mathrm{HF}$ (indicating the expected low sorption on the cation and anion resin at high acid concentration) but increase (as expected for cation resin sorption) in the $0.1 \mathrm{M} \mathrm{HNO}$. second contacts. Uranium sorptions in the first and second contacts are similar for both OIER and RESIN testing. The RESIN results are slightly better than are those of the OIER tests. 
Plutonium $\mathrm{K}_{\mathrm{d}} \mathrm{s}$ for the $6 \underline{\mathrm{M}} \mathrm{HNO}_{3} / 0.3 \mathrm{M}$ HF first contact (RESIN tests) are higher than the analogous $4 \underline{\mathrm{M} \mathrm{HNO}} 3$ (OIER tests), reflecting the sorption of the anionic Pu(IV) complex on the anion resin favored by higher acid. The sharply lower $\mathrm{K}_{\mathrm{d}} \mathrm{s}$ in the dilute nitric/oxalic acid contacts for both test sets with added sludge show the effectiveness of this reagent in leaching plutonium.

\subsection{Dissolution Coefficients}

The fractions of analyte dissolved in the various leach treatments are given in Table 14. These fractions are calculated by dividing the quantity reporting to solution (in the leachate) by the total quantity present in the leach test (leachate plus residue). These data are given in Tables 6 through 11 for ${ }^{137} \mathrm{Cs}, \mathrm{U}$, ${ }^{239,240} \mathrm{Pu},{ }^{241} \mathrm{Am},{ }^{238} \mathrm{Pu}{ }^{241} \mathrm{Am}$, and total alpha, respectively.

Table 14. Dissolution Coefficients

\begin{tabular}{|c|c|c|c|c|c|c|}
\hline Test & ${ }^{137} \mathrm{Cs}$ & Uranium & ${ }^{239,240} \mathrm{Pu}$ & ${ }^{241} \mathrm{Am}$ & ${ }^{238} \mathrm{Pu}{ }^{241} \mathrm{Am}$ & Total $\alpha$ \\
\hline OIER 5 & 0.671 & 0.829 & 0.950 & 0.824 & 0.839 & 0.824 \\
\hline OIER 6 & 0.540 & 0.642 & 0.861 & 0.639 & 0.661 & 0.639 \\
\hline OIER 7 & 0.466 & 0.932 & 0.981 & 0.836 & 0.851 & 0.836 \\
\hline OIER 8 & 0.601 & 0.918 & 0.979 & 0.819 & 0.851 & 0.819 \\
\hline RESIN 1 & 0.704 & 0.862 & 0.959 & 0.794 & 0.817 & 0.881 \\
\hline RESIN 2 & 0.691 & 0.866 & 0.956 & 0.803 & 0.821 & 0.873 \\
\hline RESIN 3 & 0.794 & 0.758 & 0.905 & 0.615 & 0.658 & 0.780 \\
\hline RESIN 4 & 0.587 & 0.822 & 0.951 & 0.556 & 0.620 & 0.789 \\
\hline
\end{tabular}




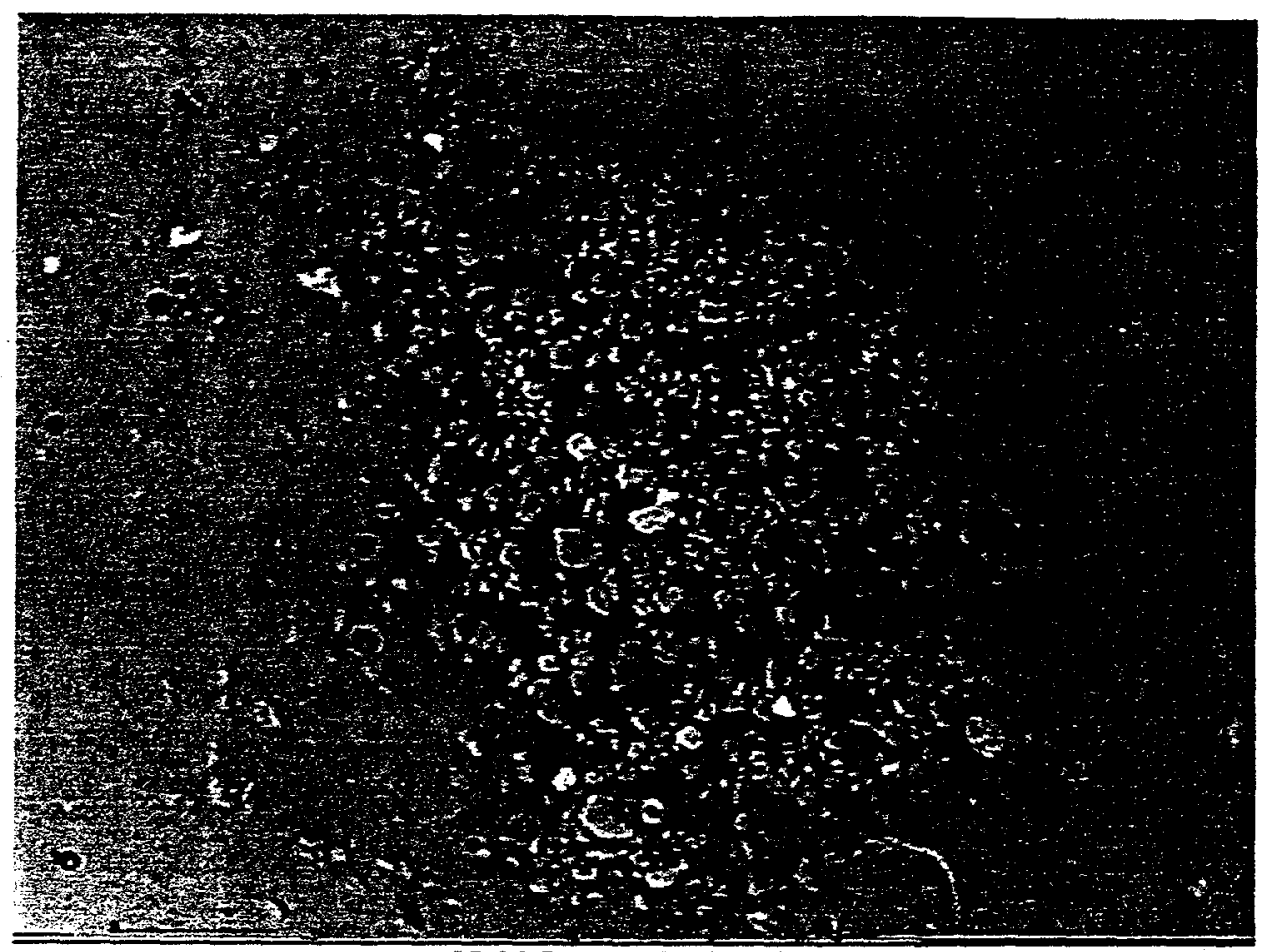

H-08 Inorganic Fraction

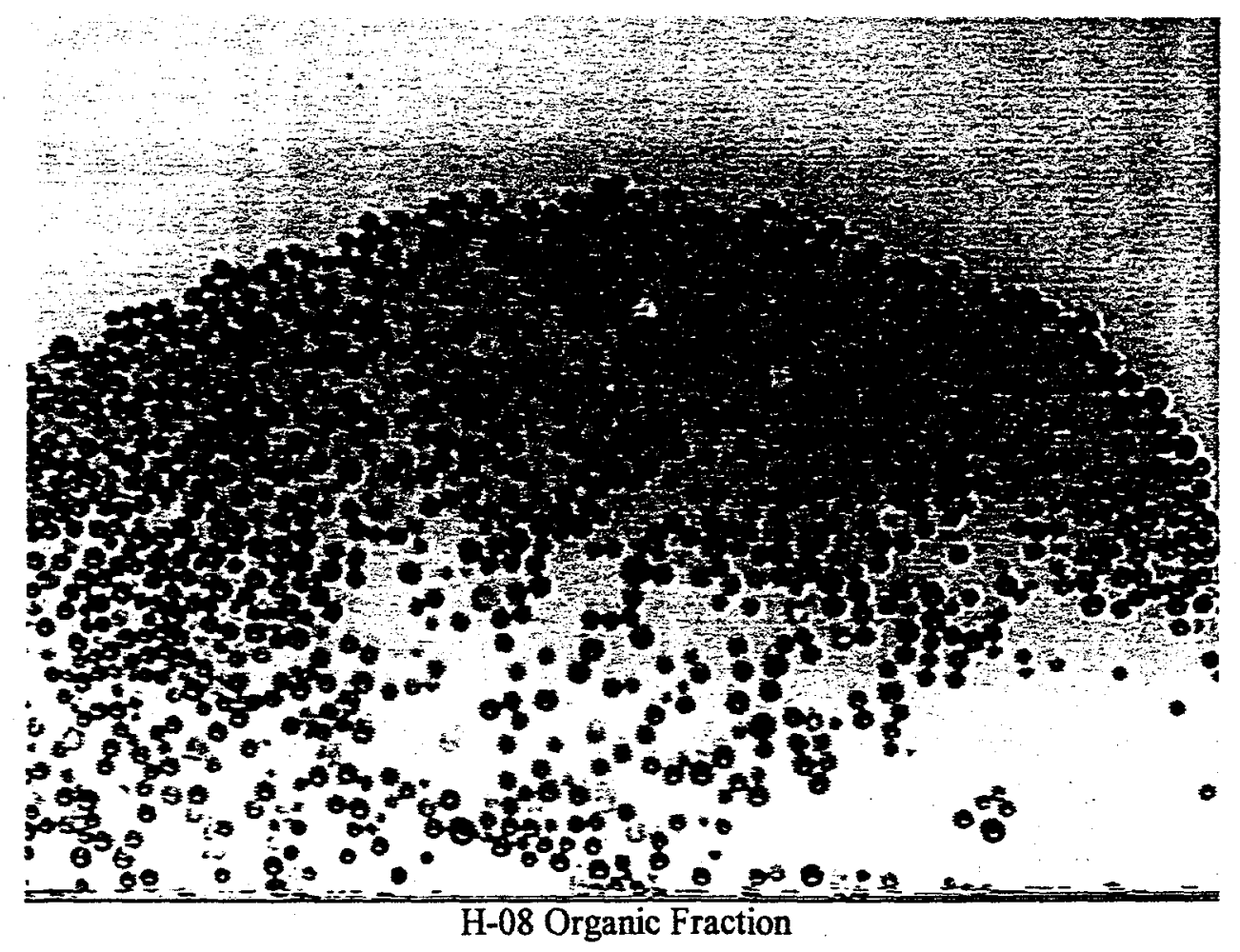

Figure 1. Dried and Fractionated Material from Sample H-08. 


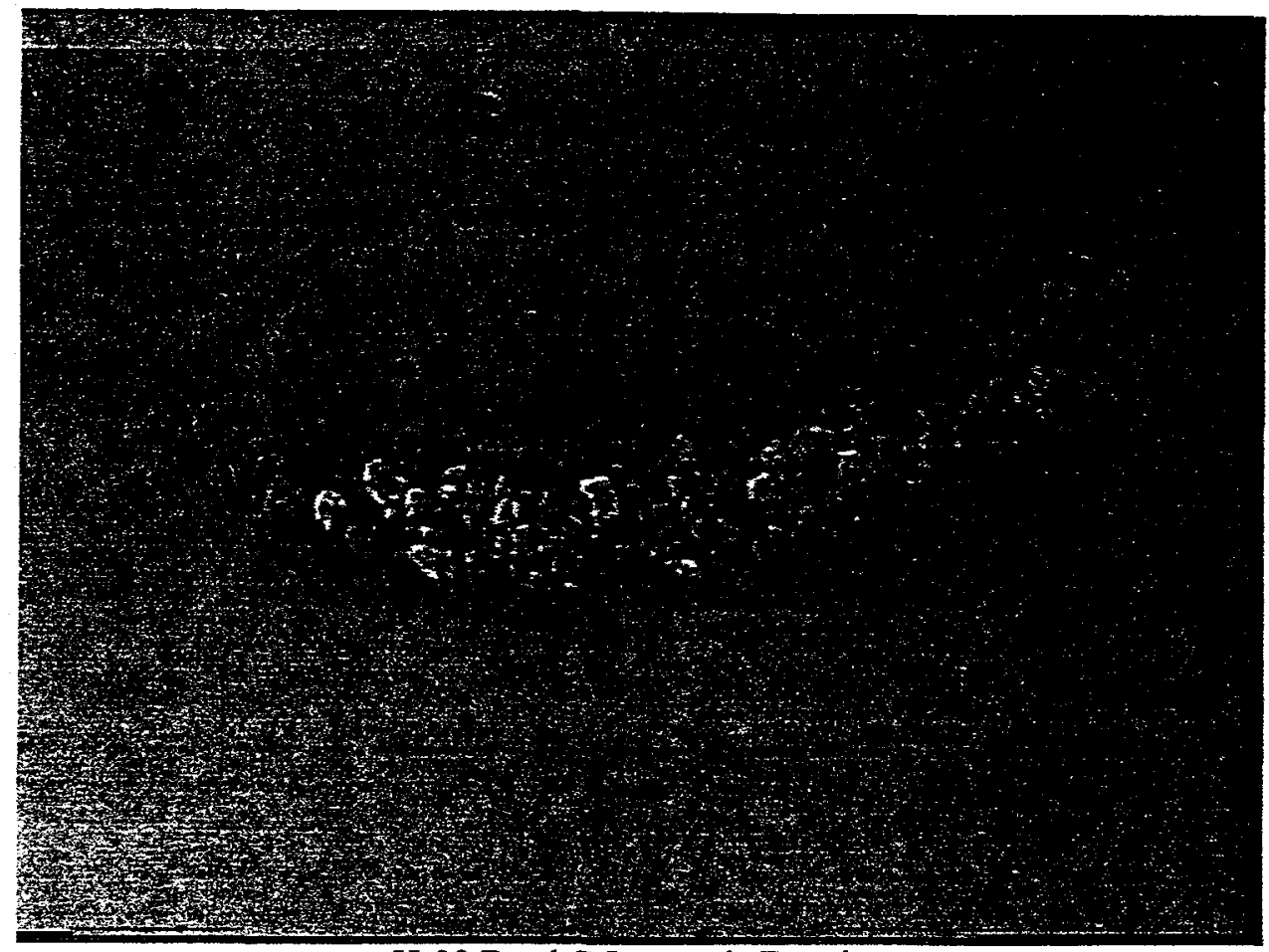

H-08 Bead G Inorganic Fraction

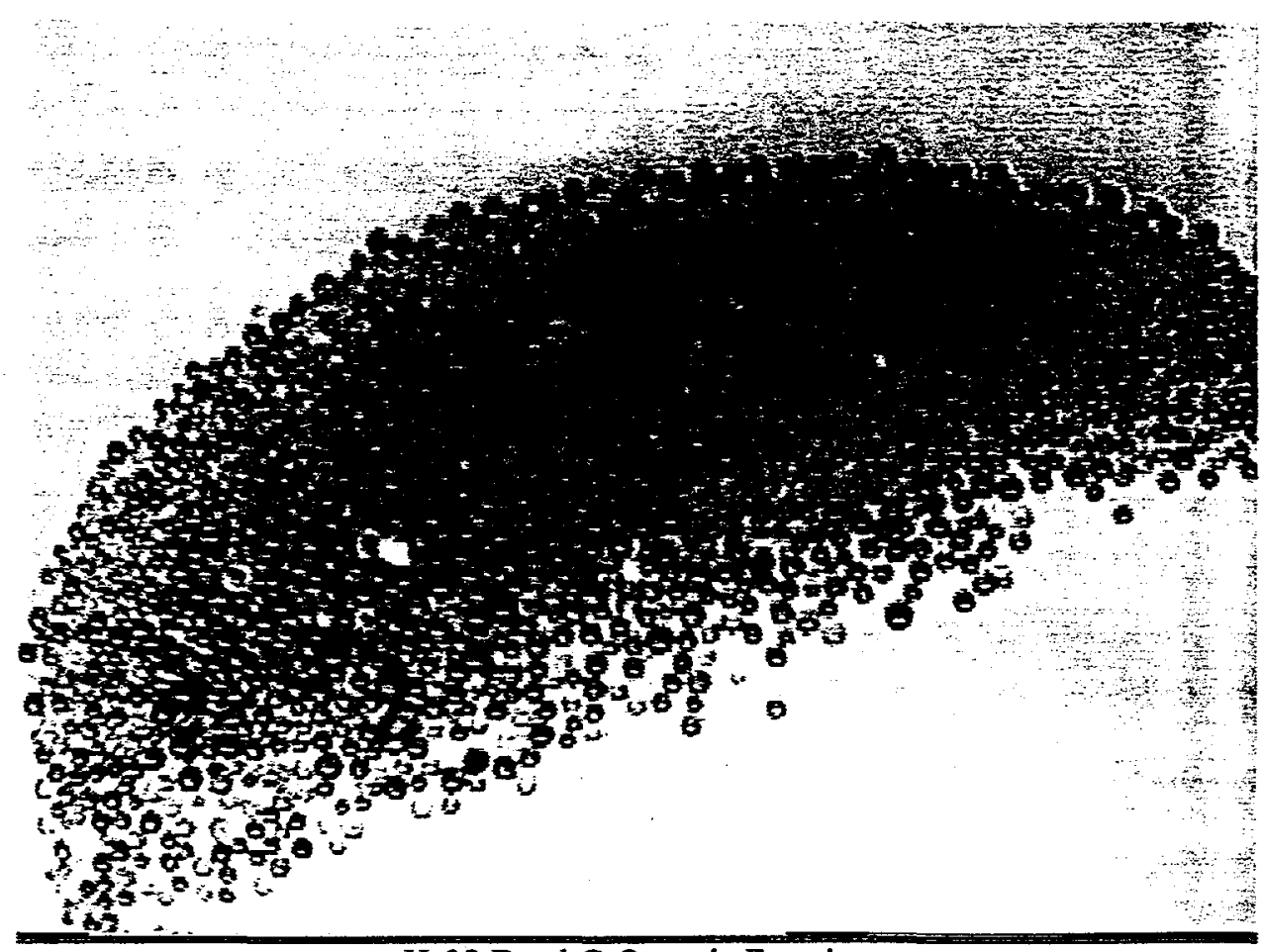

H-08 Bead G Organic Fraction

Figure 2. Dried and Fractionated Material from Sample H-08 BEAD G. 


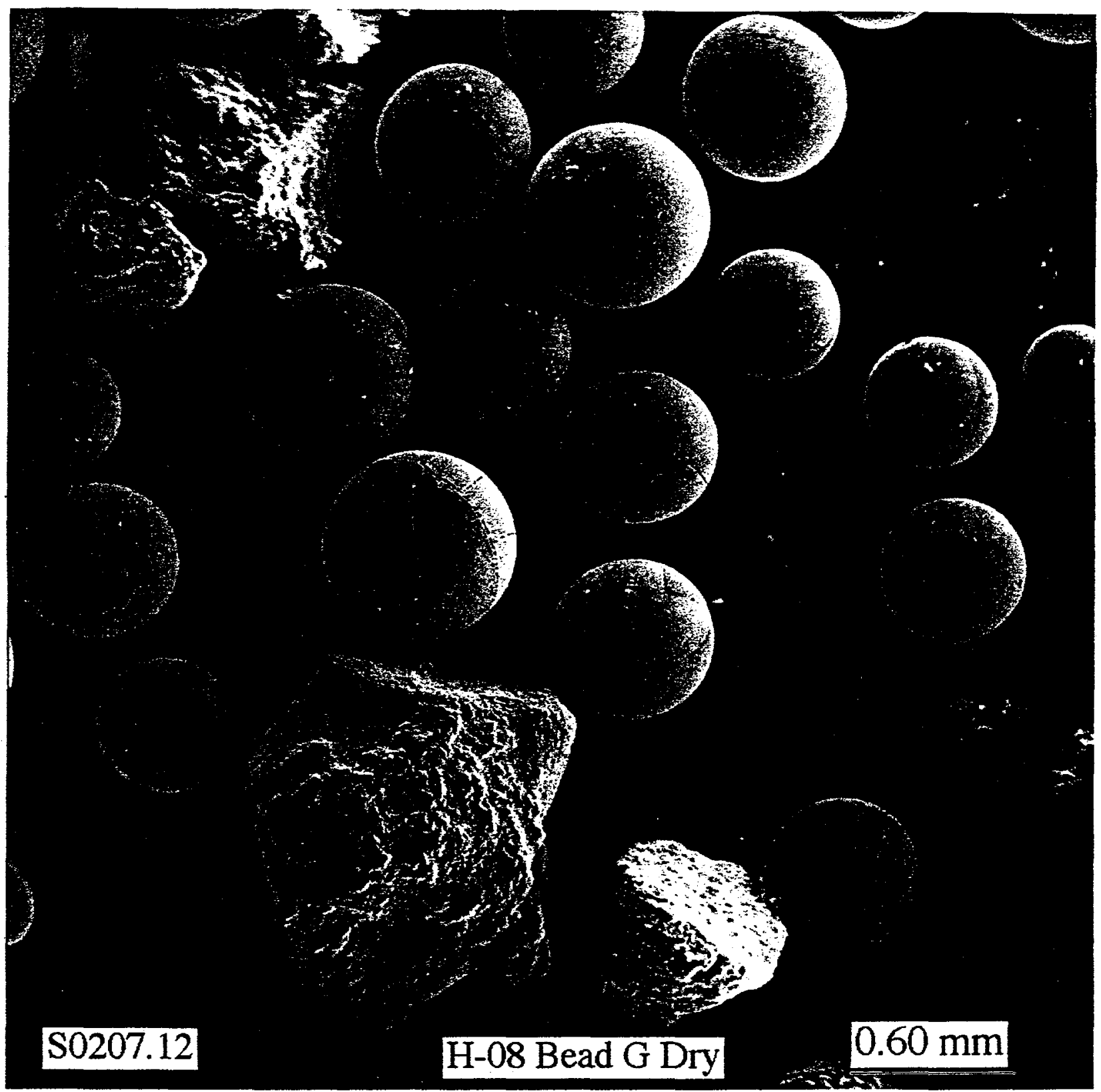

NOTES: 1 . Zeolon-900 particles are the irregular-shaped pieces; $\mathrm{Si}$ :Al ratio about $6: 1$ by energy dispersive $\mathrm{X}$-ray spectrometry, EDS

2. Zeolon-900 particles are highly porous (look like coral under stronger magnification)

2. OIER are the spherical beads; some show cracking; hemispheres observed in other images

3. anion resin (less sulfur found in resin) has a pitted orange-peel surface (see bead at left center edge)

4. cation resin (more sulfur found) has a smooth surface

5. fine particles seen adhering to resin surface even for this water-rinsed material

6. anion resin contains higher concentrations of $\mathrm{Si}, \mathrm{Cl}$; anion resin also contains $\mathrm{S}$ (likely as $\mathrm{SO}_{4}{ }^{2-}$ ) though not as much as cation resin

7. cation resin contains higher concentrations of $\mathrm{Na}, \mathrm{K}, \mathrm{Mg}, \mathrm{Ca}, \mathrm{Al}, \mathrm{Fe}$

Figure 3. Scanning Electron Photomicrograph of H-08 BEAD G IX Materials. 


\subsection{References}

Bechtel. 1998. ERDF Waste Acceptance Criteria, BHI-00139, Rev. 3, Table 3, Bechtel Hanford, Inc., Richland, Washington.

Delegard, C.H. and D.E. Rinehart. 1998. Radionuclide Leaching from Organic Ion Exchange Resin. PNNL-12105, Pacific Northwest National Laboratory, Richland, Washington.

Delegard, C.H., D.E.Rinehart, C.D.Carlson, C.Z.Soderquist, and S.K.Fadeff. 1998. Radionuclide Leaching from Residual Solids Remaining After Acid Dissolution of K East Area Sludge Composite. PNNL-12106, Pacific Northwest National Laboratory, Richland, Washington.

Dodd, D.A. 1998. Engineering Study: Recommendation for Removing Radionuclides from Organic Ion Exchange Resin in K Basin Sludge. HNF-2802, July, 1998, Numatec Hanford Company, Richland, Washington.

Flament, T.A. 1998. Testing Strategy to Support the Development of K Basin Sludge Treatment Process, HNF-2574, Rev.0., Numatec Hanford Company, Richland, Washington.

Pool, K.H., C.H. Delegard, A.J. Schmidt, B.M. Thornton, and K.L. Silvers. 1998a. Results from Test 4, "Acid Digestion of Mixed-Bed Ion Exchange Resin." PNNL-12107, Pacific Northwest National Laboratory, Richland, Washington.

Pool, K.H., C.H. Delegard, A.J. Schmidt, and K.L. Silvers. 1998b. Results from Test 1, "Acid Digestion of Zeolite and Hydrated Iron Oxide in Proportions Representative of Analyzed Sludge Materials, "letter report 28510-04 to Duke Engineering \& Services, Hanford. January 1998, Pacific Northwest National Laboratory, Richland, Washington.

Reas, W.H. 1949. "Identification of Plutonium(IV) Oxalate Complexes in Oxalic Acid Solutions." paper 4.9 in The Transuranium Elements, G.T. Seaborg, J.J. Katz, and W.M. Manning (editors), McGraw-Hill Book Company, New York.

Schmidt, A.J., G.S. Klinger, and P.R. Bredt. 1998. Evaluation of Ion Exchange Materials in $K$ Basin Floor Sludge and Potential Solvents for PCB Extraction from Ion Exchange Materials, PNNL-12108, Pacific Northwest National Laboratory, Richland, Washington.

Schmidt, A. J., K. L. Silvers, P. R. Bredt, C. H. Delegard, E. W. Hoppe, J. M. Tingey, A. H. Zacher, T. L. Welsh, and R. B. Baker.' 1999. "Supplementary Information on K-Basin Sludges." HNF-2367, Rev. 0. Fluor Daniel Hanford, Inc., Richland, Washington. 